\title{
The Concept of Tacit Knowledge - A Critique
}

\begin{abstract}
Summary
This article questions the concept of tacit knowledge as the basis for our conceptual understanding of practice. The first part of the article is a critical introduction to the concept of tacit knowledge. It is emphasized that this concept is situated in various academic practices and not defined and homogeneously but in accordance with issues and intentions significant for these practices.

The second part of the article outlines some consequences of conceptualizing practice as basically a matter of tacit knowledge. It is argued that tacit knowledge should be seen in relation to the growth of professions in modern society and to the need to legitimate them. It is further claimed that as a legitimating concept tacit knowledge may bring about various problems leading to a marginalization of specific experiences, to social uniformity, to the reappearance of individualism and to the maintenance of a dualistic view of knowledge.
\end{abstract}

I $n$ recent years concepts of intuitive expertise and tacit knowledge have become increasingly important factors in discussions concerning knowledge and learning in practice. Apparently, new studies of learning and knowledge in practice have turned our notions of knowledge and intuition upside down. The following quotation is an excellent illustration of this:

\begin{abstract}
"We once asked chess champion of the Netherlands, Jan Donner, why women had never risen to the highest levels in chess. Donner's puzzling reply was that women in chess lack intuition" (Dreyfus \& Dreyfus, 1986, p. 25).
\end{abstract}

This quotation leads to the following questions: Would it influence our understanding of learning and knowledge if we conceptualized what we do in practice on the basis of concepts such as tacit knowledge and intuitive expertise? ${ }^{1}$ Would it bring us new insights, or would the above quotation set the scene for reductive prejudices regarding, for example, men and women?

The main purpose of this article is to call attention to our conceptual approach to practice. The notion of tacit knowledge is one way of conceptualizing practice based on assumptions about a specific kind of knowledge. Due to the key concept of tacit knowledge, this will primarily be an epistemological approach to practice. Epistemology is

\footnotetext{
1 This article focuses specifically on the concept of tacit knowledge which is the conceptual basis for a number of other concepts within the area, among others Dreyfus and Dreyfus' (1986) concept of intuitive expertise. However, Dreyfus and Dreyfus reject the concept of tacit knowledge and prefer the concept of intuition (Dreyfus \& Dreyfus, 1986, p. 152). This distinction will be discussed later in the article.
} 
here understood as a specific way of portraying the relationship between subject and world where this relationship is primarily seen as a matter of the subject knowing the world. In this article I shall discuss the consequences that emerge if we accept tacit knowledge as the conceptual foundation for our understanding of practice.

The article is divided into three parts. In the first part the concept of tacit knowledge is introduced, and in the two following parts I outline different consequences of adopting tacit knowledge as the basis of our conceptual approach to practice.

In the first part an account of Polanyi's introduction of the concept of tacit knowledge is followed by an outline of approaches which have reinterpreted the concept of tacit knowledge in the last couple of decades. The work of Dreyfus and Dreyfus and different interpretations of Wittgenstein represent this approach in which especially the inexpressible dimension of tacit knowledge is central. Finally, a more cognitive approach by Wagner and Sternberg is introduced in which tacit knowledge is related to a specific kind of practical intelligence.

In the second part of the article it is argued that tacit knowledge should be seen in relation to the rise of professions in modern society and the need to legitimate these professions. The new professions legitimate themselves by importing a scientific approach to knowledge and learning. In this context, tacit knowledge can be seen as a compromise between remaining scientific, on the one hand, and developing a concept containing the specific and unique experiences of the participating professionals, on the other hand.

The third part of the article claims that tacit knowledge makes practice more inaccessible to the participants. It is argued that professional practice may be mystified and become reified for the participants. More specifically, by legitimating practice as a matter of epistemology, it is argued that social uniformity, individualism and a dualistic view of knowledge can be seen as consequences of using the concept of tacit knowledge to explain professional practice.

\section{Background of the concept}

The following is a critical presentation of the concept of tacit knowledge. Rather than giving an abstract philosophical account of the concept, different reasons for introducing and using the concept of tacit knowledge shall be outlined in order to situate it in different academic contexts. By taking this approach, we come to realize that the concept of tacit knowledge is by no means a homogeneous concept. On the contrary, it is defined in various ways depending on the context and the kind of issues and problems dominating this particular context. In fact, the concept has been used in various contexts, covering widely different and at times almost conflicting matters.

Originally, the Hungarian philosopher Polanyi introduced the concept of tacit knowledge but, as we shall see below, in recent years the concept has attained several meanings. First, I shall isolate Polanyi's original understanding of the concept of tacit knowledge as tradition-bound rules and then present other understandings of it.

\section{Tacit Knowledge as Knowledge of Tradition}

In 1958 Polanyi introduced the concept of tacit knowledge in his work "Personal Knowledge" (Polanyi, 1994). One of Polanyi's motives for working with this concept was to make it function as a strategic concept. Polanyi was a professor of chemistry and concerned with the growing political influence on science. In that context he developed the concept of tacit knowledge to ensure that sci- 
ence would remain independent and not be governed by external interests (Carlgren, 1990c; cf. also Rolf, 1991). As I shall argue in this paper, it is a recurring feature in the history of the concept of tacit knowledge that it tends to transform power relations into questions of knowledge and epistemology.

According to Polanyi, the concept of personal knowledge is a combination of subjective experience and collective rules for action embedded in various traditions. For instance, in court the judge's sentence is based on an expert opinion within the legal tradition of that particular area. This means that another judge who experiences a similar situation and a similar case, will rule in nearly the same way and reach the same result. It is still a matter of the judge's personal opinion which is based on how he or she applies the various rules in practice. This opinion, or professional assessment, is the personal dimension of the acts which the judge carries out in connection with his or her professional duties.

On Polanyi's account, the concept of tacit knowledge is a central characteristic of personal knowledge emphasizing that it is partly tacit.

According to Polanyi, tacit knowledge always involves epistemology. He also suggests that tacit knowledge is to be understood as a combination of concept and sense impression. An individual's experiences are based on his or her own activities and combined with concepts passed down by tradition.

Tradition is passed down through the concepts of language and by using language as a tool in different situations. Language as such has no directions for use, but tradition has. Tradition implies a number of tacit rules for how to use a language. Thus, language becomes the place where tradition and individual experience meet (Rolf, 1991). According to Polanyi, tacit knowledge is acquired through apprenticeship. In many ways, apprenticeship becomes the paradigmatic illustration of learning precisely because tradition is passed down through learning by doing, by submitting to authority and trusting the experienced practitioner (Polanyi, 1994). The important point here is that Polanyi's interpretation of tacit knowledge is socially based on tradition and embedded in a number of implicit rules which can, in principle and if necessary, become explicit.

\section{Tacit Knowledge as an Inexpressible Dimension of Practice}

In recent years Polanyi's original concept of tacit knowledge has been reinterpreted; that is, tacit knowledge is now understood as something which, in principle, is inexpressible. This reinterpretation is particularly based on research from the research center on working life, "Arbeidslivscentrum", in Stockholm on how the introduction of information technology has influenced our understanding of knowledge and learning (cf. Göranzon, 1990). Here Polanyi's concept of tacit knowledge was reinterpreted in light of the introduction of new computer technology. As mentioned earlier, one of Polanyi's motives for adopting the concept of tacit knowledge was to develop a strategic concept to safeguard scientific practice from external political interference. A strategic thinking also motivated the reinterpretation of the concept of tacit knowledge at Arbeidslivscentrum. One purpose here was to develop a conceptual tool to protect local working communities against increased rationalization through the introduction of new computer technology. Yet, this strategic use of the concept of tacit knowledge again creates new problems due to the fact that questions of power are transformed into matters of recognition and knowledge (Carlgren, 1990c). These new problems will be ad- 
dressed in the third part of this article. What follows now is an account of the inexpressibility version of tacit knowledge which was primarily developed in the research at Arbeidslivcentrum in Sweden.

There are two versions of this inexpressibility with regards to understanding tacit knowledge. One version is related to Wittgenstein's concept of practice and the other to Dreyfus and Dreyfus' (1986) concept of intuitive expertise.

\section{The Wittgensteinian Approach}

Polanyi's concept of tacit knowledge has been reinterpreted in light of Wittgenstein's late philosophy. This Wittgenstein-inspired reinterpretation was made by the Norwegian philosopher Johannessen (1988a; 1988b). Johannessen bases his reinterpretation on von Wright's interpretations of Wittgenstein's work. Von Wright presents Wittgenstein's emphasis on practice as an argument in favor of a kind of pre-knowledge (Johannessen, 1988a, p. 357). Basically, Johannessen argues that Wittgenstein distinguishes between knowing linguistic rules and following them. To follow linguistic rules is quite a different matter from knowing them. According to Wittgenstein, the crux of the matter is how we follow rules since this is how they are constituted and hence become meaningful. The problem is to know how to follow them in the actual situation. This calls for something more than rules.

In other words, there is more to using a language than merely knowing the abstract, linguistic rules. Wittgenstein characterizes the rule-constituting actions as practice. To follow a rule is practice, and when we follow a rule, we do not consciously interpret every rule before applying it. Rather, our use of rules is defined by practice, that is, by the historical context in which we follow them (Johannessen, 1988b).
Tacit knowledge, then, describes how we apply our knowledge in practice, that is, how the rules are followed in the actual situation. According to Johannessen's interpretation of Wittgenstein, practice is basically tacit because it is part of our way of living and cannot substantiate its own foundation in a verbal discourse. Fundamentally, practice is based on something that is inexpressible or, in Wittgenstein's words, "practice speaks for itself" (Johannessen, 1988a). Practice is characterized by aspects of inexpressibility, that is, some aspects of practice can, in principle, never be expressed linguistically.

The major difference between Wittgenstein's and Polanyi's approaches is that, acording to the Wittgensteinian approach, some elements of tacit knowledge can never be made verbally explicit. Furthermore, according to Polanyi's approach to tacit knowledge, rules for actions are central both in the traditions and in the concept of tacit knowledge. In the Wittgensteinian approach the dimension of inexpressibility is central and a matter of addressing the activities which go beyond the linguistic rules and are based on life forms which speak for themselves.

\section{The Approach by Dreyfus and Dreyfus}

Dreyfus and Dreyfus are critical of Polanyi's definition of tacit knowledge (Dreyfus \& Dreyfus, 1986, p. 152). They find that tacit knowledge, as Polanyi defines it, pays too much attention to the mind as something that is operated by rules. Instead, they suggest that the concept of intuition is more precise and operative than the concept of tacit knowledge. This has led to that Dreyfus and Dreyfus' concept of intuition is frequently used synonymously with the concept of tacit knowledge within the approach of inexpressibility (cf. Benner, 1984; Josefson, 1988a; Göranzon, 1990). Dreyfus and Dreyfus' understanding of intuitive expertise is unfolded 
in their model of skills. Their five-stage model of skill acquisition shows how the novice practitioner acts exclusively on the basis of the context-free rules that were acquired during his or her theoretical training. After having experienced how patterns repeat themselves in practical situations, the practitioner will then develop from being an experienced novice into a competent practitioner and will finally become an expert. An expert is a practitioner who primarily acts on the basis of intuition (Dreyfus \& Dreyfus, 1986). The transition from acting on the basis of theoretical rules to acting on the basis of intuition is a consequence of how the person in question becomes emotionally involved in practice. Thus, Dreyfus and Dreyfus describe how the individual practitioner, because of his or her own actions and experiences from a number of similar situations, will gradually become aware of these similarities and thereby able to predict how situations develop. In that way, the practitioner accumulates knowledge of which he or she is not conscious.

As mentioned above, Dreyfus and Dreyfus replace the concept of tacit knowledge by the concept of intuition. In other words, they do not recognize tacit knowledge as a type of knowledge but reserve the concept of knowledge for a relatively narrow concept of rules. Furthermore, Dreyfus and Dreyfus transform the concept of tacit knowledge into a concept of intuition as a sense belonging to the individual, hence, abandoning the social perspective implied in different ways by Polanyi and Wittgenstein.

\section{Tacit Knowledge as Practical Intelligence}

Inspired by intelligence research, Wagner and Sternberg $(1985 ; 1986)$ and Wagner (1987) use the concept of tacit knowledge as practical intelligence. They find the tacit aspect of knowing to be a central characteristic of practical intelligence since neither tacit knowledge nor practical intelligence are expressed or taught directly and both are primarily learned in informal settings (Wagner \& Sternberg, 1985, p. 439). Practical intelligence is a different concept of intelligence than the predominant, academic and formally oriented concept of intelligence. Based on a series of experiments on critical events, Wagner and Sternberg (1986) attempted to prove the existence of tacit knowledge. Here tacit knowledge, or practical intelligence, refers to an implicit concept of experience operationalized in the following themes: to be able to manage one's career, how one optimizes one's reputation and how one succeeds in "selling" one's projects to one's superiors. In these experiments, selected people were given a critical description of an event within their professional area and then asked to answer some questions. Two groups were selected: a group of academic psychologists and a group of managing directors. Both groups were divided into subgroups: a group of so-called experts (the experienced people) and a group of so-called novices (the newly educated). Naturally, the researchers expected the experts to possess a large amount of professional tacit knowledge and the novices to possess only a small amount. The results of these experiments showed that apparently there is a substantial difference between the tacit knowledge of experts and novices within different areas. In every respect it turned out that the experts were better at managing their careers - a fact which, according to Wagner and Sternberg, proves the existence of tacit knowledge.

\section{Summary}

There are many different ways of understanding the concept of tacit knowledge. Three different ways were presented above: tacit knowledge as (1) embedded in tradition, 
(2) an inexpressible dimension of practice and (3) an aspect of practical intelligence. Furthermore, one might argue that these various definitions of tacit knowledge are mutually exclusive. Tacit knowledge is both depicted as a kind of knowledge which is rule governed (the Polanyi-tradition) and as something which is beyond rules (the Wittgensteinian tradition). It is presented both as a personal experience embedded in tradition (the Polanyi tradition) and as an individual ability (Dreyfus and Dreyfus' interpretation of intuition). Finally, tacit knowledge is depicted both as an intuition that lies beyond any conscious reflection (Dreyfus and Dreyfus' interpretation) and as an experience based non-verbal intelligence of promoting one's career (Wagner and Sternberg's suggestion).

Besides introducing the concept of tacit knowledge, the first part of this article emphasizes that the mutually exclusive and noncoherent way of using the concept does not merely serve academic interests. The definition and circulation of the concept of tacit knowledge can be understood in relation to fulfilling various motives in different settings. By situating the definition and use of the concept, it is stressed that concepts are not only a way of representing the world, but also a way of influencing and changing it. This line of thinking will be pursued in the second and third part of the article in which a number of consequences of using the concept of tacit knowledge will be outlined.

How, then, is a concept to be understood? The traditional way of understanding a concept would be to follow the author's presentation, his or her more or less consistent use of it, the extent of its documentation, and so forth. Or one might look at it critically, attempt to falsify it, find inconsistencies in the author's use of it, and so forth.

My critical way of reading and comprehending the concept of tacit knowledge dif- fers from these views. I consider tacit knowledge, like any other circulating artifact, to be determined by special, historical and societal conditions. There are certain reasons why the concept has become increasingly popular, why it has been applied by certain groups, why it is distributed in different contexts, and so forth. Thus, the concept of tacit knowledge cannot merely be considered a concept that describes something out there "in real life". It must be seen as a concept that is created, circulated and applied in relation to a number of different interests. Whereas the presentation and reading of a concept is traditionally separated from the effect it may have on a broader societal context, my presentation postulates that it is not possible to separate the understanding of a concept from its actual use, effect and consequences on societal practice.

\section{Professions and technical rationality}

In order to understand the circulation and distribution of the concept of tacit knowledge, one must understand the development of new professions in connection with the establishment of the modern welfare state. In 1960 large parts of the population in the Western world were occupied in the primary production (the extraction of raw material - farming, mining, fishing industry, etc.) or in the secondary production (the manufacturing of goods). In the future, the majority of the population will be occupied within the service sector - the new professions (Fjord Jensen, 1987). This implies an expansion in the number of people employed in the service industry within the educational sector and the national health services (e.g., doctors, nurses, educationists, teachers, etc.). In the total labor force the number of professionals increased from $4 \%$ in 1900 to $8 \%$ in 1950 and to $13 \%$ in 1966 (Schön, 1983, p. 18). Num- 
bers from the expanding profession of psychology in Denmark illustrate precisely this development. Around 1974 approximately 2,500 psychologists were organized while today the figure has increased to nearly $7,000 .^{2}$

The new professions legitimate themselves with science claiming that by applying scientific theories and methods practitioners are able to solve the problems they encounter in the practice of their work. The scientific nature of the knowledge and theory that are focused on here originates from positivism (Schön, 1983, p. 29). That is, knowledge is presented as an object available for users in relation to any specific situation. The predominant knowledge and learning model of the new professions can, in short, be characterized as technical rationality which consists in an instrumental solution to a well-defined problem that is laid down by scientific knowledge and theory (Schön, 1983). Thus, technical rationality is regarded as exempt from subjective experiences, appearing as objectified in already existing procedures and formalities which are at people's disposal in the actual situation. In other words, this understanding of knowledge does not focus on the practitioner's actions and experiences in the actual situation; on the contrary, it focuses on the importance of following pregiven directions of how to do things in practice.

This understanding of knowledge has different consequences.

One consequence of technical rationality is that the meaning of context, experience and action is neglected in the educational context and that the practitioners' experiences become unnecessary. This way of depicting knowledge is dominant and lies at the heart of a number of educational institutions' conception of knowledge. It will disregard

2 It is no coincidence that the presenters of tacit knowledge often conduct their research in new professions. the concrete conduct of professional practice, and it creates a distinction between education and work practice within the profession.

Another consequence involves our understanding of learning. Learning is basically seen as a transmission of knowledge from someone who already knows to someone who does not know. Learning becomes a technical question related to finding the most efficient ways of making the transmission of knowledge function (cf. Dreier, 2002).

The third, and possibly most important, consequence is that in the post-industrial society technical rationality appears to be legitimating a number of dominating institutions and professions (cf. Wackerhausen, 1992). Today the need to legitimate one's actions in relation to a scientific codex plays an important role in almost all modern institutions (cf. Molander, 1990). Knowledge is no longer legitimated in relation to its emancipating or educative character; on the contrary, knowledge has to increase the performance of social systems. Indeed, it must possess the characteristic of problem solving implied by the core definition of technical rationality. Knowledge is merely seen as valid when it can increase the efficiency of the system (Lyotard, 1991).

A central issue for the different professions that appeared in the wake of the modern welfare state is that they face many intricate problems which technical rationality can no longer solve. The problems which the professional practitioner faces require another set of themes than the one provided by technical rationality. Hence, the new professions encounter a number of dilemmas. On the one hand, in order not to lose prestige the professions must define themselves in relation to the scientific discourse, and only those professions that define themselves as scientific are recognized. On the other hand, technical rationality is apparently not very efficient in relation to the particular problems the practi- 
tioners are confronted with (Schön, 1983). Because of this dilemma, a need is created for a concept that is able to contain the experiences of professional practitioners and at the same time be included and legitimated by scientific discourses. As mentioned above, the growing interest in the concept of tacit knowledge is based on these dilemmas.

\section{The consequences of tacit knowledge in practice}

Thus, tacit knowledge can be considered a conglomerate or a compromise of the two tendencies through which the professions seem to develop. On the one hand, the professions require scientific legitimacy. On the other hand, the professions need to identify and define practice in accordance with the actual experiences of the members of the profession. However, as I shall argue below, the concept of tacit knowledge does not make professional practice more accessible to the participants. On the contrary, by legitimating practice as an epistemological matter, professional practice becomes mysterious and reified and, consequently, more inaccessible to the participants. I shall argue that the use of tacit knowledge will lead to a marginalization of the participants' experiences, to social uniformity, individualism and a dualistic view of knowledge.

\section{Tacit Knowledge and Marginalization of Experiences}

By introducing tacit knowledge as a legitimating foundation for professional practice, I argue that central experiences will be marginalized or neglected. Issues of politics, ethics and values will be marginalized in favor of discussions about knowing the world.

As mentioned above, the central tendency for the new professions is to seek legitimacy in the scientific environment. Most research that addresses the concept of tacit knowledge tends to focus on this issue. In connection with research on how the introduction of new technology influences the workplace, one of the pioneers in the re-launch of the concept of tacit knowledge, Göranzon, writes that, "close cooperation with philosophers has been of great importance" (Göranzon, 1983, p. 8, my translation). In other words, in order to legitimate the specific (tacit) knowledge of the professional practitioners, science must legitimate it as valuable in an epistemological sense. Göranzon suggests that professional practitioners seem to be in possession of a practical intellect. The aim is to conceptualize practice in new ways by means of the concept of tacit knowledge and similar concepts, thus, protecting the specific knowledge existing in certain work communities. The concept of tacit knowledge is well suited for this purpose. Most research on tacit knowledge points to the fact that the concept is difficult to define, let alone identify empirically, and several authors imply that the use of the concept of tacit knowledge is embedded in strategic considerations. Molander emphasizes that the concept is difficult to define, but by using it one will contribute to an increase in "social and political status" of the actors (1990, p. 108).

By returning to the historical analyses that seem to legitimate tacit knowledge, these authors often focus on the threat that the computerization of society presents to local work communities. Janik's formulation makes this very clear:

Tacit knowledge is intimately connected to the kind of qualitative differentiation that exists between products of human experience and products of machine efficiency (Janik, 1989, p. 10, my translation).

Here Janik emphasizes that tacit knowledge defends the kind of knowledge which is related to human experience and which is defined 
in contrast to the computerization of this knowledge.

The problem with conceptualizing work practice as a question of different ways of understanding knowledge will result in that certain problems become conspicuous while other problems are not considered at all. In other words, this way of conceptualizing a work practice as an epistemological problem implies that some problems appear to be central while others are neglected. The fact that some tasks change in connection with the computerization of workplaces will become an epistemological issue between tacit and explicit knowledge. Only issues that fall within this area are acknowledged. Other aspects of the issue disappear or are neglected. As an illustration of this, we may mention the research project at Arbeidslivscentrum called PASS. PASS, i.e., perspektiv på datasystemutveckling (perspective on data system development), is a research project which led to the development of many of the different meanings of the concept of tacit knowledge (Göranzon, 1983). For instance, in the interviews from this research project many of the interviewees assert that the installment of computers will lead to increased surveillance, central control, isolation of the individual employee, unemployment, and so forth (cf. Göranzon, 1983, p. 216). But these issues are not emphasized in connection with the discourse on tacit knowledge. The result of placing issues of power in an epistemological framework is that some aspects disappear while others emerge. All questions concerning moral, ethics and politics disappear in favor of discussions of new ways of knowing the world.

\section{Tacit Knowledge Creates Social Uniformity}

We have now seen that the concept of tacit knowledge is also intended to promote the in- terests of a number of different professions, and we have seen how it originates from a critique of the general trend to reify knowledge. In the following, I shall argue that the concept of tacit knowledge must necessarily function as an unclear, yet central concept for members of the work community and profession.

Tacit knowledge can be considered a concept which apparently creates a certain kind of coherence within the profession or the work community, not because of its clarity or illustrative power but because it holds the inexpressible factor that binds the members together in a status of obscurity. Tacit knowledge stands as a concept of the inexpressible factor or as a category that does not identify anything, but which is of value because it states that the members are bound to each other by a shared accumulation of knowledge. The heterogeneity and division of labor of the social field of action in relation to specific tasks are transformed into a homogeneous accumulation of knowledge. In order to clarify these themes, we may draw on Ryle's concept of category-mistake.

From Ryle's perspective, the concept of tacit knowledge can be considered a category-mistake. A category-mistake denotes that the description of actual characteristics of things, events or people may be confused with the general category for this behavior (Ryle, 1976). The category-mistake may cause a double-world thinking. ${ }^{3}$ Ryle used the concept of category-mistake to point out that Descartes' differentiation between conceptual matter (res cogitans) and physical matter (res extensa) is a category-mistake. In connection with this category-mistake, phi-

\footnotetext{
3 Double-world thinking may be defined as a dogma which maintains that both body and mind exist; that both physical and mental processes occur; that there are both mechanical causes of corporeal movements and mental causes of corporeal movements (Ryle, 1976, p. 23).
} 
losophers have been of the opinion that a form of conceptual matter actually did exists, but in reality different categories were confused linguistically. An action-oriented aspect of a practice was mystified and turned into a non-specific object.

The same argument can be made in relation to tacit knowledge. We may look at how the professional practitioner performs a number of qualified actions, and we may identify these actions as expressions of tacit knowledge. However, the very moment we find tacit knowledge as an actually existing kind of knowledge, we make a category-mistake by assuming that tacit knowledge really exists. The concept of tacit knowledge will become the new ghost in the machine.

Ryle's implication that the categorical confusion is a mistake, is, however, not necessarily correct in this casd. The categorical confusions may serve a purpose. The concept of tacit knowledge actually seems to have a unifying function as an indubitable element for the members of the profession. Furthermore, tacit knowledge hinders non-members from getting access to take over vital work assignments and thereby gain influence. It is no coincidence that the first to circulate the concept of tacit knowledge was Kuhn (Kuhn, 1970, p. 43-45). According to Kuhn, tacit knowledge covers precisely the common rules that create the implicit basis for the paradigms which define the scientific standards. Contrary to Kuhn, the concept of tacit knowledge offers no possibility for establishing an internal, critical dialogue that may renew and change the profession from within, so to speak. There is very little chance that the professions themselves can establish changes, shifts in paradigms or carry out other radical changes based on the concept of tacit knowledge. In this sense, the concept of tacit knowledge is preservative in relation to already established forms of practice. The concept of tacit knowledge will, hence, keep those possible conflicts and oppositions at a distance which might actually transform and change the profession or the work community by means of critical dialogue.

\section{The Reappearance of Individualism}

As mentioned above, the concept of tacit knowledge implicitly served as a glue for scientific communities of practice. I shall argue below that the concept of tacit knowledge creates the illusion that work communities are unified by a homogeneous core of knowledge that is generally agreed upon, thereby distracting attention from the fact that practice is constituted by a number of social positions that are defined in relation as well as in contrast to each other. The concept of tacit knowledge distracts attention from the fact that conflicts and oppositions are the dynamic reasons for development and change and leads to a focus on the abilities and capacities of the individual.

It is, therefore, in line with this thinking that the concept of tacit knowledge seems to re-establish an individualistic approach to professional practice. ${ }^{4}$ This return to individualism must have its background in internal rivalry and power struggles among professions. It is not a matter of professions functionally dividing the various work fields between themselves but of rivaling professions struggling to define and delimit attractive work fields in relation to the interests of their profession. One example may be the ongoing conflict between teachers and educationists in Denmark as to who should be the key figures in connection with the introductory periods of school attendance for small children.

4 Here tacit knowledge is, of course, understood as a dimension of inexpressibility, intuition or practical intelligence while, according to Polanyi's understanding of tacit knowledge, traditions, that is, collective historical actions, are central. 
A similar professional conflict may be found within the national health services where doctors, nurses and assistant nurses try to dominate different work assignments.

In connection with these rivalries, the concept of tacit knowledge plays an important role. It is no mere coincidence that the profession of nursing, in a squeeze between doctors and assistant nurses, found the concept useful (cf. e.g. Josefson, 1988a; Benner, 1984). The concept of tacit knowledge displaces the focus on social position and power-oriented relations to link actions and their legitimacy to the tacit knowledge of the individual professional, hence focusing away from social interaction, oppositions and power struggles towards the capacities of the individual. The individual is, in other words, de-contextualized.

The individual practitioner has gained a prescriptive right to tacit knowledge expressed by intuition and feelings as legitimate grounds for action. Tacit knowledge is to define the reputation and social status of the individual while other aspects are left out. The following example shows how tacit knowledge may appear as a personal capacity and not be related to a certain social status. The example is from Benner's studies of the development of nurses from novices to experts, and it shows the expert nurse's capacity in connection with the work of diagnosing mental illness in patients. Benner's studies of the development of nurses is the empirical basis for the skill model on intuitive expertise by Dreyfus and Dreyfus. Benner writes:

\footnotetext{
"When I tell a doctor: the patient is psychotic, I do not know how to legitimize it? But I am never wrong. Because I am extremely familiar with psychoses. And I know it so well that I know what it is, and I trust that" (Benner, 1984, p. 32).
}

This example illustrates how, based on tacit knowledge, the practitioner's action is legitimated as professional intuition in relation to members of another profession, the doctors. In reality, the practitioner acts on the basis of his or her specific social position which provides the person with power and incontestable authority. The infallible diagnosis may just as well be due to the fact that the nurse is positioned in an institutional community in which she has the power of classification and in which no other member of the community can question this classification. In other words, it is difficult to distinguish between the classification of the patient and the stigmatizing exertion of power. The introduction of tacit knowledge into practice, thus, contributes to shifting the focus towards the capacities of an ahistorical individual and away from a socially situated, relational understanding of knowledge and the individual. Tacit knowledge de-contextualizes the different positions within the profession.

\section{Dualism Maintained}

The concept of tacit knowledge maintains rather than transcends the dualistic perspective on knowledge. As mentioned above, tacit knowledge has been defined as an alternative to technical rationality within the epistemological paradigm. The traditional way of dividing intuition and tacit knowledge from scientific rationality has been to present this as a division between an unclear, mythical and magical line of thought, on the one hand, and a systematic, scientific line of thought, on the other hand (cf. Lave, 1988). This dualism is captured in contrasting the concept of tacit knowledge with technical rationality, and it is repeated in many of the stories related to the concept of tacit knowledge, for instance, in Josefson's presentation of the intuitive and tacit actions of the expert nurse (Josefson, 1988b).

Josefson presents an example in which a nurse with thirty years of professional experience - mainly with post-surgery patients - 
met a patient who said that he was fine and okay after his operation. This statement was supported by objective, observable indications. Yet, the nurse felt that something was wrong. She sent for a young doctor who did not find anything wrong and blamed the nurse for having sent for him for no reason. However, the patient then died during the night. The nurse had noticed that something was out of the ordinary but could not explain how she had arrived at this conclusion.

Josefson's example illustrates how the medical, systematic, scientific line of thought fails while intuition dominates. The story shows that it is a matter of two basic kinds of knowledge in opposition to each other. The same dualism can be found in the five-stage model of learning developed by Dreyfus and Dreyfus (1986). Their model also clearly distinguishes between the types of knowledge that are related to context-free rules, on the one hand, and intuitive pattern recognition, on the other hand.

In this respect, the values have simply been turned upside down. The Western, systematic rationality ("the doctor") is not associated with positive values. On the contrary, the local cultures (the "primitive" people) and professional practitioners ("the nurse") now possess and define the positive values. The dualism between rationality and magic still exists, only with a different set of value poles. Whereas technical rationality is a perverted version of the Western thought of the enlightenment, one may consider the concept of tacit knowledge to be a caricature of the ideal knowledge of romanticism.

The problem with this clear-cut dualism between the two types of knowledge is that it implies a particular understanding of the social world. This dualistic understanding implies that an already objective world exists, independent of human actions or beings. That has been termed the "prejudice of an objective world' (Merleau-Ponty, 1981; Kvale,
1968). The implicit assumption of this notion is that we must clearly realize that this objective world is present in all our actions. When that turns out not to be the case, the concept of tacit knowledge is invented. Polanyi exemplifies tacit knowledge with the wellknown observation that one can ride a bike without actually knowing what one does and yet continue riding it. The illustration of the bike ride supports the thought that we must apparently not be completely aware of the already existing world and anything we do in it, and if that is not the case the auxiliary hypothesis of "tacit knowledge" must be introduced. The rational line of thought constructs tacit knowledge as a convenient auxiliary hypothesis. If, alternatively, we consider the world from the perspective of the actor in a social context, it is possible to maintain that due to the fact that we exist in time and space as well as in a social world - actions must be considered unfinished business. Our participation will hence always include an unclear dimension. This dimension is, however, not to be considered a type of knowledge. On the contrary, it is an implicit consequence of the fact that our existence is constantly modified by our participation in a social world.

\section{Summary and new questions}

In this article I have taken a critical stand on the concept of tacit knowledge in discussions of professional practice. As a point of departure I raised the question, what would be the consequences of approaching practice as an epistemological matter rather than in terms of activity. I outlined three different ways of conceptualizing tacit knowledge, namely: tacit knowledge as tradition, as an inexpressible dimension of practice and, finally, as a kind of intelligence. And I argued that these definitions of tacit knowledge are not homogenous but mutually exclusive.

Furthermore, I looked critically at tacit 
knowledge by relating it to the growth of professions in modern society. It was argued that tacit knowledge could be seen as a compromise between legitimating the professions in accordance with scientific standards and offering a concept about the specific experiences of professional practitioners. However, this way of conceptualizing practice from an epistemological perspective gave rise to new questions and contained a number of important problems.

As argued above, the new professions must find ways of legitimating themselves. Using the concept of tacit knowledge for this purpose tends to turn it into a black box which makes practice mysterious and inaccessible. However, we should also take into account which phenomena the concept of tacit knowledge is pointing at. Social practice consists of a mixture of social habits, historically grounded modes of actions, knowledge distributed in work practices and tools. Although a large part of one's participation in a social practice is not articulated verbally, that does not entail that this kind of participation is founded on tacit knowledge. Rather than placing habitual, collective elements of actions and tool-mediated participation in the category of tacit knowledge, it seems more appropriate to categorize and describe these activities concretely as they take place in practice.

As an alternative to using the concept of tacit knowledge I argue for the necessity of not letting the concrete practice out of sight when a practice is legitimated. Rather than transforming practice into categories of knowledge, it is important to describe and relate to the ongoing practice as it unfolds in all its diversity. In other words, we need to account for the collective nature of activities in practice rather than to focus on different categories of knowledge. Rhetorically speaking, one could state that knowledge needs to be moved from the head and placed in the world again, that is, described as it progresses in social activities with tools. We need to ask critically what is gained by conceptualizing practice as tacit. Rather than placing particular activities into categories of knowledge, we need to describe in detail what happens in social situations. The concept of tacit knowledge actually does address the notion of habits directly or indirectly. But we need to approach habits as more than efficient routines. An understanding of social habits calls for historical analyses of the bodily nature of social practice. Furthermore, we ought to ask critically for whom specific kinds of knowledge are tacit? Is it for the observer - the scientist -, for the practitioner or for the client? And finally, we need to ask whose knowledge is tacit in a social practice? Here we need to focus on social positions and on how knowledge is used to maintain social positions and privileges. I shall end this article with Erwin Straus' words about the unconscious, now slightly changed to cover the concept of tacit knowledge: "The tacit knowledge of the practitioner is more often than not the verbal and explicit theories of the social scientist" (freely interpreted from Straus, 1958, p. 151).

\section{References}

Benner, P. (1984). From Novice to Expert: Excellence and Power in Clinical Nursing Practice. New York: Addison and Wesley.

Bohlin, H. (1989). Datorisering och tyst kunskap. Dialoger, nr. 10, 18-27.

Carlgren, I. (1990a). Den svårformulerade yrkeskunskapen. Nordisk Pedagogik, Vol. 10 (3), 97-98.

Carlgren, I. (1990b). Tyst kunskap och frågan om praktikerens forandring. Nordisk Pedagogik, Vol. 10 (3), 167-172.

Carlgren, I. (1990c). Vem talar om tyst kunskapoch varför? Interview med Aant Elzinga. Nordisk Pedagogik, Vol. 10 (3), 115-119. 
Dreier, Ole. (1994). Personal Locations \& Perspectives: Psychological Aspects of Social Practice. In Psychological Yearbook Vol. 1, Copenhagen: Museum Tusculanum Press, 1994, 63-90.

Dreier, O. (1997). User Perspective in Change During Treatment. In Skriftsserie Sundhed, Menneske, Kultur, nr. 1, Aarhus Universitet: Institut for Filosofi.

Dreier, O. (2002) Learning and Personal Trajectories of Participation. Paper presented at the Ninth Biannnual conference of the International Society for Theoretical Psychology, Calgary, Canada.

Dreyfus, H. (1992). What Computers Still Can't Do. A Critique of Artificial Reason. Cambridge, MA: The MIT Press.

Dreyfus, H. \& Dreyfus, S. (1986). Mind over Machine, NewYork: The Free Press.

Dreyfus, H. \& Dreyfus, S. (1997). Apprenticeship, Experts and Intuition - an interview by Steen Wackerhausen. Nordisk Pedagogik. Vol. 17 (3). 204-208.

Fjord Jensen, J. (1987). Det tredje. Den postmoderne udfordring. Valby: Amadeus Forlag.

Göranzon, B. (red.) (1983). Datautveklingens Filosofi. Malmö: Carlsson \& Jönsson Bokförlag AB.

Göranzon, B. (1990). Det Praktiske Intellektet. Malmö: Carlssons Bokforlag.

Janik, A. (1989). Tyst kunskap, regelfoljande och inlaring. In: Dialoger, nr. 10, 6-17

Johannessen, K. (1988a). The Concept of Practice in Wittgenstein's Later Philosophy. In Inquiry 31, 357-369.

Johannessen, K. (1988b). Tankar om tyst kunskap. In: Dialoger nr. 6 1988, 13-29.

Josefson, I, (1988a). Från Lärling till mästare. Om kundskap $i$ vården. FoU rapport, 25, Lund: Studenterlitteratur.

Josefson, I, (1988b). Language and Experience. In Göranzon, B. \& Florin M. (eds.) Artificial Intelligence, Culture and Language: On Education and Work. Cambridge: SpringerVerlag, 71-77.

Kuhn, T. (1970). The Structure of Scientific Revolutions. Chicago: The University of Chicago Press.
Kvale, S. (1968). 'Unconscious Processes' in Concept Formation. An Empirical Fact or a Theoretical Construction. In Acta Psychologica, 28, 1968, 344-362.

Kvale, S. (1997). Research Apprenticeship. Nordisk Pedagogik. Vol. 17 (3), 186-195.

Lave, J. (1988). Cognition in Practice: Mind, Mathematics, and Culture in Everyday Life. Cambridge: Cambridge University Press.

Lyotard, J.F. (1991). The Postmodern Condition. Minneapolis: University of Minnesota Press.

Merleau-Ponty, M. (1981). Phenomenology of Perception. London and Henley: Routledge \& Kegan Paul.

Molander, B. (1990). Kunskapers tyste och tystade sidor - ett fors $\varnothing \mathrm{k}$ till oversikt. Nordisk Pedagogik, Vol. 10 (3), 99-114.

Nyeri, J.C. (1988). Tradition and Practical Knowledge. In: Practical Knowledge: Outlines of a Theory of Traditions and Skills, J. C. Nyeri \& B. Smith (eds.), London: Routledge and Kegan Paul, 17-51.

Perby, M. L. (1990). The Inner Weather Picture. In Göranzon \& Florin (eds.) Artificial Intelligence, Culture and Language: On Education and Work. Cambridge: Springer Verlag, 77-83.

Polanyi, M. (1994). Personal Knowledge, London: Routledge and Kegan Paul.

Polanyi, M. (1966). The Tacit Dimension. Routledge and Kegan Paul.

Polanyi, M. (1969). Knowing and Being. London: Routledge \& Kegan Paul.

Rolf, B. (1991). Profession, tradition och tyst kunskap: En studie i Michael Polanyis teori om den professionella kunskabens tysta dimension. Lund: Nya Doxa Bokförlaget.

Rosenbrock, H. H. (1990). Engineering as an Art. In Göranzon, B. \& Florin, M. (eds.) Artificial Intelligence, Culture and Language: On Education and Work. Cambridge: Springer Verlag, 95-101.

Ryle, G. (1976) The Concept of Mind. Middlesex: Penguin Books Ltd.

Schön, D.A. (1983). The Reflective Practitioner, How Professionals Think In Action, New York: Basic Books. 
Schön, D.A. (1987). Educating the Reflective Practitioner - Toward a New Design for Teaching and Learning in the Professions. London: Jossey Bass.

Straus, E.W. (1958) Aesthesiology and Hallucinations. In May, Angel and Ellenberger, (eds.), Existence. A New Dimension in Psychiatry and Psychology. New York: Basic Books, 139-170.

Wackerhausen, S. (1991). Polanyis Begreb om Tavs Viden - En Kritisk Skitse. Undervisningsnoter/arbejdspapir.

Wackerhausen, S. \& Wackerhausen, B. (1993).

Tavs viden og pædagogik, Dansk Padagogisk Tidsskrift, Vol. 4, 190-201.
Wagner, R.K. \& Sternberg, R.J. (1985). Practical Intelligence in Real-world Pursuits: The Role of Tacit Knowledge. Journal of Personality and Social Psychology, 48, 436-458.

Wagner, R.K. \& Sternberg, R.J. (1986). Tacit Knowledge and Intelligence in the Everyday World. In Sternberg, R. J. \& Wagner, R. K. Practical Intelligence. Nature and Origins of Competence in the everyday world. Cambridge: Cambridge University Press, 51-84.

Wagner, R.K. (1987). Tacit Knowledge in Everyday Intelligent Behavior. Journal of Personality and Social Psychology, Vol. 52, no. 6, 1236-1247.

Wittgenstein, L. (1994). Filosofiske undersøgelser. København: Munksgaard. 